\title{
Nihilism and the Problem of Future: Biodiversity Destruction As One of the Great Dangers of Technology?
}

\author{
Jelson Oliveira \\ (Pontifical Catholic University of Paraná, jelson.oliveira2012@gmail.com )
}

One of the best known things about my native country, Brazil, is the biodiversity of the Amazon. Whoever knows this region of the world is able to easily understand that one of the most important marks of life as a whole is diversity, an impressive phenomenon when we pay attention to numbers: $7,010,000 \mathrm{Km}^{2}, 9$ countries (Bolivia, Peru, Colombia, Venezuela, Guyana, Suriname, French Guiana, Ecuador and Brazil), 5\% of the earth's surface, 40\% of South America, $20 \%$ of world reserves of unfrozen water, $34 \%$ of the world forest reserve, 1,100 rivers, the largest river in the world (Marañon-Solimõ esAmazonas, with $6,671 \mathrm{Km}$ ), $15 \%$ of the water entering the oceans, $30 \%$ of the world's fauna and flora, around 55,000 species of plants (22\% of the world's species), 1000 birds, 300 mammals (among 4,650 of the world), 550 reptiles, 163 amphibians, 3,000 fish, millions of insects and microorganisms. Of course, the Amazon is not the only region of the world with such a diversity of living beings, but it is certainly one of the most important scenarios for those who want to understand life and how species diversity is one of the central criteria for how each one of these life forms can survive in time and space. One important thing to note is that the biodiversity of the Amazon also includes the socio-diversity, that is, the different forms of human life that live there: 23 million of people, 688 municipalities, 163 indigenous groups of people, with 208,000 people $(60 \%$ of the indigenous population of Brazil), 160 different languages in 14 linguistic trunks and 11 isolated languages. Faced with this scenario, Euclides da Cunha, an important Brazilian writer, said: "the Amazon, even from a strictly physical aspect, we know it to shreds. More than a century of research and persevering an invaluable literature, numerous monographs, shows it to us in countless instalments of aspects. [...] Human intelligence would not support, suddenly, the weight of that power loaded reality" (Cunha 2000, 23).

This means that the human mind collapses in the face of such a great reality in terms of biodiversity, because the reason cannot account for all the elements that make up this great spectacle of life. This is the problem that begins to appear when we think on the technical-scientific rationality that tends to dominate (Hans Jonas refers to it as a "will to unlimited power" [Jonas 2013, 34]) to use reality exclusively for the benefit of the human being. The result of 
this typically modern use of technology is the reduction of life: through monoculture, planting exotic forests (such as eucalyptus and pine, for example), the large-scale breeding of animals, the standardization of diet, habitat destruction, the introduction of exotic species, the overuse of natural resources, the application of agrochemicals and other agricultural inputs, the introduction of new species and the soil and water pollution, etc.

In such way, the modern will to domination and exploit nature is, through technology, designing a new future. The main face of this new reality is the total control over life, just as transhumanists, for example, insist. Therefore, it is increasingly necessary to reduce diversity to something knowable: only what is knowable can be controlled. This is the kind of future that has been shown by science fiction films: in the name of equality - and therefore for something good - we can and we must reduce diversity. It means that the multiplicity of life forms should be reduced to the rules of rationality, albeit at a high cost in the sense that the complexity of life may remain an enigma for human instrumental reason. The resulting problem of this process is that the impoverishment of biodiversity also means the impoverishment of human life. It means that the future of our lives becomes a kind of game, through a very risky bet that makes us enjoy all the natural resources in the present in an irresponsible way, compromising the satisfaction of the needs and also the existence of future generations. This process of impoverishment of life is therefore an unsustainable process and requires an ethical position. This is the central concern of the work of the Jewish-German philosopher Hans Jonas: for him, it's necessary and even urgent to look after the future with more responsibility.

\section{Hope Or Fear?}

In that sense, the technological power of engendering our future, both from an anthropological point of view (by reconfiguring the man by the so-called technological convergence, something that is seen as an overcoming of the human into the posthuman and its transhuman versions) and an evolutionarycosmological point of view (which includes the general reform of life and the environment) brings the problem of the future to the centre of philosophical reflection. Overall, there are two perspectives: either we look after the future with hope or with fear. The first hypothesis is based on a positive, utopian outlook and the belief that technology is the instrument of healing the limits imposed by nature and has in Ernst Bloch one of its first and most forceful thinkers (after Francis Bacon). Following a Marxist view, The Principle of Hope (three volumes: 1954,1955, 1959) begins with the conviction that a classless society guided by work and technology could lead humanity to happiness. This proposal is criticized by Hans Jonas in his The Imperative of 
Responsibility (1979), in which the hypothesis of fear is considered a necessary heuristic, i.e., an alert and an ethical alternative to utopia. Fear is, for Jonas, a benefit that provides a look into the future from the malum, i.e., the risks and the threats contained in present human actions. As a heuristic imperative, for Jonas, fear is a feeling that stimulates the reflective capacity: its internal mechanism is not a feeling of anxiety or distress or even powerlessness or weakness, but a reflective premise about dangers which become actual to the extent that the possibilities of its realization are shown. Being fear, this feeling would simply be an altered state of consciousness and it would be out of the ethical field. Therefore, it is not about creating some kind of exaggerated and anxious attention or a sensation of panic before what it is, experienced in advance from the stimulus produced by imagination. Fear, for Jonas, is not something pathological, merely derived from the sensibility of an involuntary affectation. As an ethical component, it is something practical, i.e., controlled by will and/or rationality. For that reason, fear is not a principle of paralysis or escape from danger, but it leads to face the situation in an attempt to properly orient the action, avoiding that what was imaginatively projected happen. The danger to be faced, contrary to that one which leads to escape or inertia, holds the potential of something that must be respected due to the real possibility that the threat happens.

In Jonas, fear is an element conditioned to the species' survival and to the authenticity of the image of man: that is, it is not only a political element, but cosmic and ontological, after being also ethical. But it, instead of leading to a reduction of freedom and autonomy, it would represent a possibility to its use, since the retaking of its ethical positivity assumes the character of a reflection on the possible danger. Everything works as fear was a result from an imaginative artifice of the worst prognosis towards future at a time that hope and utopian enthusiasm seemed to replace the individual and collective responsibility for the assurance of the continuation of life. Facing the danger of an ultimate evil, imagined as a risk brought by techne, Jonas makes fear an element which would prevent mankind from its disappearance, either substantial (the end of the species) or formal (the authenticity of human life). Fear is, for Jonas, an ethical alternative against hope because can be a good chance to reflect about the dangers of our actions.

That's how fear is presented as an ethical alternative before enthusiasm and naivety which the success of techne have been accepted and practiced in all fields of human society, under the label of the utopia of progress which intends to reframe and improve nature in general and the nature of man itself. For Jonas, the technical power is "drunk with itself" (Jonas 1998, 142). This utopia has moved techne forward, facing it as harmless or preferring optimistic projections of future, which on the one hand believe that technique is always used with good purposes and because of it no kind of restriction is need and on the other hand in case it causes some harmful consequence, it itself will be 
able to correct this loss. Techne, according to this view, would build up the best possibilities and the least risks, that's why it would be able to create «the best of the possible worlds», annulling the clear ambiguity of all human acts. The annulment of this ambiguity is the annulment of the ethical possibility, since ethics just exists where man is aware his acts may be either good or bad and due to it they need to be analysed by reflection.

In this sense, Jonas (and Bloch) thinks the future product of the actions of the present and takes advantage of a "comparative futurology" (a futuristic projection from the articulation of different knowledges) to invoke the need for humanity of now to be committed to the continuity of life tomorrow. The future in this case is a projected causality: it serves as a guide to present actions. How we see the future, with hope or with fear, affects our actions in the present.

As Avishag Zafrani suggested in her book Le défi du nihilisme (2014, 13) the problem of the future comes with the question of "finalism" - or finality: Bloch follows the line of the end of history determined by "an utopian tendency of human consciousness", i.e., the idea that history ends well, that there is always a "happy ending", as something inscribed "in the being of man" as something inherent, meaning, as a value. End and value are central themes in the ethical proposal of Hans Jonas, for whom fear does make us see the end as a negative projection, whose result would be the affirmation of the value and good that must be preserved. The fear, therefore, does not appear as a pessimistic concept, because the "will of negation", in this case (it is necessary to predict the evil so that it does not happen), would have a heuristic result, precisely the affirmation of the life value as a Good to be safeguarded. For Jonas, the moral obligation, therefore, is already inscribed in the being (in the sense that life says "yes" to itself, choosing the purpose and affirming its value), which gives his ethics an ontological foundation that reinserts the purpose into nature in general and life in particular. Refusing both anthropocentrism and the modern ontology of death that treats nature as a mere inert matter (and to which, consequently, life remains an indecipherable enigma, since it cannot be explained by either the materialist monism nor by idealistic monism) Jonas carries forward the ambitious hypothesis that finality and value are the characteristics of life - not just part of the human world. In Jonas, as well as in Bloch, the concepts of End and Value present themselves as an alternative to the nihilistic tendency of the philosophies of the twentieth century, especially those that were fuelled by Nietzsche's philosophy. Jonas goes even further, saying that the existentialism of Sein und Zeit, for example, keeps the same nihilistic character of the Ancient Gnostic movements, aggravated by an indifference to nature. Reflecting on the future, in this case, requires not only a new philosophy of history, but an act of rebellion against this nihilistic trend, which explains the urgency of a new ethics, whose background are some of the greatest crimes of recent human history, practiced 
in the twentieth century with the instruments provided by technological power: the atomic bomb, the experiments with humans and the extinction of life on a large scale. What is at risk, therefore, is the diversity of forms of life saved until now by evolutionary history, since the technology works according to the standardization process - by redesigning the future it standardizes it according to the values of our present time. That was what occurred during the Second World War and which is still in process today. All this could be among the most harmful consequences of nihilism.

\section{Nihilism: A crisis of Future}

Nihilism has been characterized both as a teleological crisis (there is no meaning and no purpose), as an evaluative crisis (there is no ethical guarantee on the good or evil of the actions) and as a result, from the point of view of history, as demonstrated by Gianni Vattimo in his book The End of Modernity, as a rejection of the idea of progress as a result of successive overruns. Thinking against modernity is not merely the creation of a new framework for thinking, but a refusal to think in structures, a refusal to fall into the structural logic of thought, an abdication of the foundation of the notion of thinking and, ultimately, the idea that rationality offers some foundation to understanding existence. That would be the modus operandi of the nihilistic propensity of postmodernity: a rejection of the idea of overcoming and transcendence as modern categories, which characterize the way of making history that is widely criticized by Nietzsche already in his Untimely Meditations on History. From this point of view, nihilism denies all "stable structures of being" (Vattimo 1996, VIII) and, consequently, any teleological perspective of the future, from now on, oriented by its own eventual and accidental becoming. The utopia of hope in that case faces nihilism because it recovers the teleology of an overcoming of capitalism's historical contradictions toward an ideal paradigm of society, using, for this, the technological tools. The heuristics of fear, on the other hand, recovers the idea of finality as an intrinsic biological and ethical element of living organisms, for which technology is presented as a danger. One of the most controversial forms of future projection in our days is called transhumanism. Francis Fukuyama, a notorious critic of this movement, said transhumanism "is the most dangerous idea in the world" (2004). But why is this dangerous? The denial of human diversity: the quest for control a central focus of transhumanism - requires standardization. Control is becoming predictable, uniform.

Therefore, it is possible to demonstrate how transhumanists and those who herald the improvement of the human on one side, and the so-called bioconservatives on the other, present ways of confronting nihilism, but in different ways. The first are supporters of hope; the second, of fear. The first 
design the future from their utopias and believe in technology as an ethical imperative of humankind. The second, believe that there is no guarantee that the future, built by the hands of technological power, can be good and much less than the technology can heal wounds that its herself created. In this case, in dubio pro malo. And what could the latter criticize in the first? Technology lacks a purpose, a for what, without which it is delivered to a continued progress emptied of any alternative. Technology is part of the "metaphysical neutralization of the human image": it wants to reconfigure humanity without having a model (supporters of meliorism are moved by the "ontology of 'not being yet"' or the "unfinished being", that Jonas refers to in the penultimate item of his book). In this sense, transhumanism, even presenting itself as an alternative to nihilism, would eventually fall on their own plot: [1] the absence of finality (technology never reaches a saturation point - there is always something more to be explored; it is drunk of itself; self-referenced) and [2] the lack of value (or at least a definition of the value to be pursued - who said to remember is better than to forget that to control the emotions is better than feeling them, that not to die is better than dying, etc. (Hauskeller 2014) better is not always good - say the critics of the unbridled advancement of technology, this new unchained Prometheus).

\section{Technology: A Cure or a Risk?}

The two questions above put us right in the centre of the bioethical thought of Hans Jonas and what we understand as their developments in the contemporary world, the so-called Enhancement Project of the human being widely advocated by the transhumanists (and some of the post-humanists).

Transhumanism is the philosophy (or ideology) that endorses the promises of improvement that aims to transform the human in a post-human way through technology. It is a thought that takes theoretical outlines and heated debates in the academic world but also in our daily lives, as it is assumed by many spheres of culture, from the cinema to the porn industry, supported by impressive marketing campaigns that try to convince us that is possible, necessary and even morally obligatory, to design a better future for the human being. The outlook was summed up by Michael Hauskeller, for whom the projection of the human into the future starts with the conviction that "the present condition of mankind is completely deplorable and, in fact, an unhealthy state" $(2014,131)$. This means that the human's present is only a being ontologically ill for which biotechnology is presented as a cure. One of his illnesses is his ontological and behavioural change, which prevents predictability and control; but not only human nature, but nature in general needs to be reformed according to the anthropocentric criterion characteristic of this type of process. Diversity, therefore, becomes necessarily something undesirable, something that must be denied in the name of the 
standardization of behaviours, the equality of desirable performance conditions, genetic improvement and/or the effectiveness of transgenic processes (which ultimately lead to ontological changes denying one's own "identities" in the name of a blend of elements and characteristics).

In this sense, the Enhancement Project becomes widespread as a kind of moral obligation and transhumanism gains the appearances of a medicine for humanity. This means that the old question about the medical function, the way it was formulated by Jonas in the work of 1985 Technology, medicine and ethics, for example, (especially the seventh chapter, which deals with the "medical art and human responsibility") no longer makes sense: there is no more difference between therapy and enhancement, or between cure and improvement in man, or between repairing a dysfunction and improving a function. It is now installing the kingdom where we will all finally be "equal" (and this is stated as a big advantage by transhumanists) because we will have the same powers of control, the price, to be uniform and standardized, as is strongly suggested by the Science Fiction Movies.

Jonas's projections, his questions and his concerns about the ethics of such research have never been so actual. If before, the art of medicine - now covered with new technological labels - is no longer an "art of cure", i.e. the "re-establishment of a state" (Jonas 2006, 155) who was not itself, as amended, and thus kept as a "natural state or as close to it as possible" (Jonas $2006,155)$, now medicine is presented as a change in human nature itself. The physician is not the one that heals, but "the artist's body with open ends" (Jonas 2006, 159), acting in the "uncertainty of our knowledge about the meaning of human existence" (Jonas 2006, 170) prepared by a "will to unlimited power" (Jonas 2013, 34). So For the Enhancement Project, the cure of humanity evokes, on the one hand, an ethical sense: it is necessary to cure humanity from itself; and the other, an ontological sense: the cure is not to reestablish a natural state lost but to overcome the limits imposed by nature.

Understanding the man as a being ontologically ill due to the limitations that are imposed on him by his nature (or condition) the improvement is, in itself, a therapy whose benefits are broken down into treatments aimed at controlling emotions, expanding cognitive abilities, improving relationships, enhancing sexual performance, extending life, increasing strength and beauty, preventing diseases, etc. In addition, examples of practical life and the way we access medicine and its interventions, give proof that the borders are in fact diluted in order to stress the differences seem something quite idle. We should note, however, that this finding only confirms the moral argument that the best is always good in itself. The blurring of boundaries in this case is an ingenious strategy for the utopias of continued progress biogeneticists and bioethicists carry forward. Our future is in this sense quite uncertain. In order to prevent a catastrophe, ethical thinking should be able to analyse the arguments and highlight the dangers of this type of procedure, not necessarily to cancel it, but 
to clarify its risks. We cannot let the future be a place or a state of losing the power to be diverse and different. If so, you better stop here, don't you think? It is urgent to save the Amazon. It is urgent to save life.

\section{Literature}

Cnbb (Conferência Nacional dos Bispos do Brasil). 2007. Texto-base da Campanha da fraternidade 2007. Brasília: CNBB.

Cunha, Euclides da. 2000. Um Paraíso Perdido: reunião de ensaios amazônicos. Brasília: Senado Federal.

Fukuyama, F. 2004. The World's Most Dangerous Idea. Foreign Policy, September/October.

Hauskeller, M. 2014. Better Humans? Understanding the Enhancement Project. Oxon: Routledge.

Jonas, H. 2006. O princípio responsabilidade: ensaio de uma ética para a civilização tecnológica. Tr. M. Lisboa, L. Barros Montez. Rio de Janeiro: Contraponto.

Jonas, H. 1998. Pensar sobre Dios y otros ensayos. Barcelona: Herder.

Jonas, H. 2013. Técnica, medicina e ética. Sobre a prática do princípio responsabilidade. Tradução do Grupo de trabalho Hans Jonas da ANPOF. São Paulo: Paulus.

Vattimo, G. 1996. O fim da modernidade: niilismo e hermenêutica na cultura pós- moderna. Tradução de Eduardo Brandão. São Paulo: Martins Fontes.

Zafrani, A. 2014. Le défi du nihilisme. Ernst Bloch et Hans Jonas. Paris: Hermann. 
Jelson Oliveira

(Pontifical Catholic University of Paraná, jelson.oliveira2012@gmail.com)

\title{
Nihilism and the Problem of Future
}

\begin{abstract}
Starting from the example of the Amazon, in Brazil, we intend to analyse how technology (mainly in its biotechnological face) appears as a threat to biodiversity, insofar as it acts through a reduction and standardization: technology needs to reduce diversity to something knowable to be able to control and exploit, in view of human necessities. In this sense, according to Hans Jonas, it is necessary to ask about the horizon of the future giving preference to the negative prognosis (fear rather than hope) to avoid that the harmful consequences of nihilism (marked by the absence of criteria capable of guiding technological action) affect life decisively. In this case, the Enhancement project proposed by transhumanism appears as yet another chapter in the history of risks represented by modern technology.
\end{abstract}

Keywords: biodiversity, biotechnology, nihilism, Hans Jonas

Ethics in Progress (ISSN 2084-9257). Vol. 8 (2017). No. 1, Art. \#9, pp. 147-155.

Creative Commons BY-SA 3.0

Doi: 10.14746/eip.2017.1.9 